\title{
Strategic Management of Treatment for Terrorist Prisoners in Class 1 Correctional Institution of Batu Nusakambangan
}

\section{Rachmayanthy Rachmayanthy ${ }^{1}$ (D), Okki Oktaviandi2,* (D), Padmono Wibowo ${ }^{2}$ (D), and Syahrial Yuska ${ }^{2}$ \\ ${ }^{1}$ Department of Correctional Engineering, Polytechnic of Correctional Science, 16512, Depok, Indonesia \\ 2 Department of Correctional Management, Polytechnic of Correctional Science, 16512, Depok, Indonesia \\ * Corresponding Author: okkioktaviandi49@gmail.com}

\section{ARTICLE INFO \\ Publication Info: \\ Research Article \\ How to cite: \\ Rachmayanthy, R., Oktaviandi, O., Wibowo, P., E Yuska, S. (2020). Strategic Management of Treatment for Terrorist Prisoners in Class 1 Correctional Institution of Batu Nusakambangan. Society, 8(1), 204-216.}

DOI : 10.33019/society.v8i1.171

Copyright (C) 2020. Owned by Author(s), published by Society

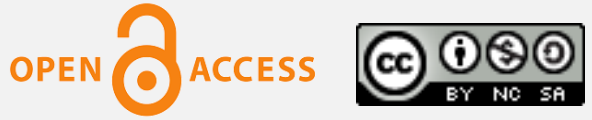

This is an open-access article.

License: Attribution-

NonCommercial-ShareAlike (CC BY-NC-SA)

\begin{abstract}
Terrorism crimes are an extraordinary crime where treatment and method require special strategic management. Strategic management for treatment the terrorist prisoners is one of the programs of the Directorate General of Correctional Affairs, Ministry of Law and Human Rights of the Republic of Indonesia, namely the management of human resources through the efforts of deradicalization for terrorist prisoners, especially in the Super Maximum Security of Correctional Institution. This research aims to provide strategic management of treatment for terrorist prisoners and the implementation of correctional institution' deradicalization programs for terrorist prisoners. This research was qualitative descriptive research. Data collection techniques using direct observation techniques in Focus Group Discussions, as well as in-depth interviews with the Head of Class 1 Correctional Institution of Batu Nusakambangan and terrorist prisoners as research objects. The results of this research indicate that the strategic management for treatment the terrorist prisoners was not completely relevant to the Regulation of the Minister of Law and Human Rights Number 35, Year 2018 and the implementation for treatment the terrorist prisoners in Class 1 Correctional Institution of Batu Nusakambangan are still very limited. There were still constraints to implementing guidelines for special prisoners of terrorists in terms of socializing regulations, human resources, and infrastructure for special treatment for terrorist prisoners.
\end{abstract}


Strategic Management of Treatment for Terrorist Prisoners

in Class 1 Correctional Institution of Batu Nusakambangan

Received: May 1, 2020;

Accepted: May 28, 2020;

Published: June 30, 2020;
Keywords: Correctional Institution; Deradicalization; Strategic Management; Terrorist Prisoners

\section{Introduction}

The concept of extraordinary crime is a serious crime that causes violations of humanity. Terrorism is one of the extraordinary crimes, which threatens peace, security, culture, and global well-being (Prahassacitta, 2016). Terrorism grows from a series of certain structural relationships between individuals and groups. However, terrorist violence is not caused by an attribute or appendage or icon of an individual or group (Deflem, 2004). One of the first principles is that terrorism is a manifestation of aggression, and it would be useful to start by considering knowledge about the general source of aggression (Borum, 2004).

In upholding the law for terrorism in Indonesia, it is regulated in the Law of the Republic of Indonesia Number 9, Year 2013, concerning the Prevention and Eradication of the Crime of Finance of Terrorism (Republik Indonesia, 2013) and Joint Regulation of the Chief Justice of the Supreme Court of the Republic of Indonesia, Minister of Foreign Affairs of the Republic of Indonesia, Chief of the Indonesian National Police, Head of the National Counterterrorism Agency, and Head of Financial Transaction Reports and Analysis Center, Year 2015, concerning the Inclusion of the People's and Corporations' Identities in the List of Suspected Terrorists and Terrorist Organizations and automatic blocking of funds of customers in the financial services sector whose identity is included in the list of suspected terrorists and terrorist organizations.

Indonesia on the soft approach of implementing deradicalization and counter-radicalization programs, in this case, Indonesia has launched Blueprint and provides a deradicalization center for terrorist prisoners.

One of the terrorist attacks in the world occurred in the United States, precisely, the attack on the twin towers of the World Trade Center in New York City on November 9 (9/11) in 2001. The attack was spearheaded by Al-Qaeda militant groups that hijacked four Boeing-767 passenger jet planes. One aircraft carrying as many as 20,000 gallons of fuel was directed to fly into the north tower of the World Trade Center while the other plane, Boeing 737 was directed to fly into the south tower of the World Trade Center. As a result, the tragedy killed around 2,996 people and injured 6,000 others (Berty, 2018).

The terrorist crime phenomenon also occurred in various regions in Indonesia, which began with the first attack in 1998 at Padang Bulan Church in West Sumatra and the Bali Bombings on October 12, 2002. The tragedy left 202 people dead and nearly 800 injured. Terrorist crime recorded history of terrorism crime in Indonesia (Putri, 2018).

Below is a series of terror actions over the past ten years in Indonesia according to CNN Indonesia (2019):

1. 2012, Grenade Thrown in front of Gladak Security Post, Solo, Central Java Province.

2. 2016, Suicide Bombing at Solo City Resort Police Station, Central Java Province.

3. 2017, Kampung Melayu Bombing, East Jakarta.

4. 2018, Church Bombing, Surabaya, West Java Province.

5. 2018, Attack on Regional Police Headquarters, Riau Province.

6. 2019, Suicide Bombing at Medan City Resort Police Station, North Sumatra Province.

The crime of terrorism grows through the process of socializing extremism which manifests itself in criminal behavior. This term is known as radicalization. In an annual report published by the Royal Canadian Mounted Police in 2010 entitled "Departmental Performance Report

Copyright (C) 2020. Owned by Author(s), published by Society. This is an open-access article under the CC-BY-NC-SA license. https://doi.org/10.33019/society.v8i1.171

205 
2009-2010" (Royal Canadian Mounted Police, 2010), radicalization is the process in which individuals are introduced to messages and ideological belief systems, which openly encourage the movement of moderate and general beliefs to extremist views that lead to hardline radicalism. Several factors motivate individuals exposed to radicalism, including personal, emotional, and psychological alienation seeking identity, and revenge for family members, previous harassment, and imprisonment.

The Directorate General of Correctional Affairs through The Regulation of Minister of Law and Human Rights Number 35, Year 2018, concerning Revitalization of Correctional Program, conduct prisoners' guidance with the aim that prisoners will not repeat criminal acts and have social skills when they return to the community. This regulation not only described correctional management as a method of treatment for prisoners but also for detainees and clients (Kementerian Hukum dan Hak Asasi Manusia Republik Indonesia, 2018). More specifically, guidance on treatment for terrorist prisoners must follow the rules and guidelines set by the Directorate General of Correctional Affairs. There is a very high risk in guiding terrorist prisoners such as harmful for other prisoners, endanger others, make explosives, and use sharp weapons. Following the qualifications of specific criminal prisoners offenses namely Qualification A (Kementerian Hukum dan Hak Asasi Manusia Republik Indonesia, 2017).

Based on the Correctional Database System, it stated that there was a significant increase in the number of prisoners in Indonesia dated October 7, 2019. Based on the Correctional Database System record, there were 267,595 prisoners in 522 Correctional Institution Unit (CIU) with an occupancy rate of $194 \%$. It is important to know that treatment for terrorist prisoners must follow the rules and guidelines, which stated that one prisoner is for one prisoner cell, so special placement is required for terrorist prisoners. Based on the Regulation of Minister of Law and Human Rights of Republic of Indonesia Number M.HH-07.OT.01.01, Year 2017, Class 1 Correctional Institution of Batu Nusakambangan is a Correctional Institution for high-risk prisoners with super-maximum security. The capacity of Class 1 Correctional Institution of Batu Nusakambangan is 94 prisoners, currently has 114 prisoners. The number of prisoners exceeds the total available capacity.

Based on the Correctional Database System in October 2019, there were 18 terrorist prisoners in Class 1 Correctional Institution of Batu Nusakambangan, with classification as followers and low-level militants for ideologies or hard-line radicals. Class 1 Correctional Institution of Batu Nusakambangan which is a Correctional Institution with super-maximum security, which was built in a special area of Nusakambangan Island, has an important role in supporting the Correctional Program of the Directorate General of Correctional Affairs. The aim of the program is to provide optimal treatment for terrorist prisoners, including guiding religious awareness, guiding national state awareness, guiding legal awareness, and psychological counseling. After undergoing the training program, special terrorist prisoners, through assessment sessions and correctional observer teams, will be placed according to the level of need and risk in Correctional Institutions with a lower security level.

\section{Literature Review}

\subsection{Strategic Management for Terrorist Prisoners}

Strategic management is a set of basic ways and strategies in decision making, which are made within the framework of top management to be implemented to achieve goals (Mappasiara, 2018). Strategic management in handling terrorist prisoners can be implemented with the method of separating terrorist prisoners with the highest level of radicalization to the lowest level of radicalization (Sumpter et al., 2019).

Copyright $\odot$ 2020. Owned by Author(s), published by Society. This is an open-access article under the CC-BY-NC-SA license. https://doi.org/10.33019/society.v8i1.171 
This research used the theory of strategic management according to Wheelen and Hunger's period. This theory stated that strategic management plays a very important role in organizations, especially for performance (Tapera, 2014). According to Wheelen and Hunger, there are 3 benefits of strategic management, which consist:

1) A clearer sense of strategic vision for the firm

2) A sharper focus on what is strategically important

3) Improved understanding of a rapidly changing environment

From these three points, four basic elements of Wheelen and Hunger are formed, known as Environmental Scanning, Strategy Formulation, Strategy Implementation, and Evaluation and Control (Wheelen \& Hunger, 2011)

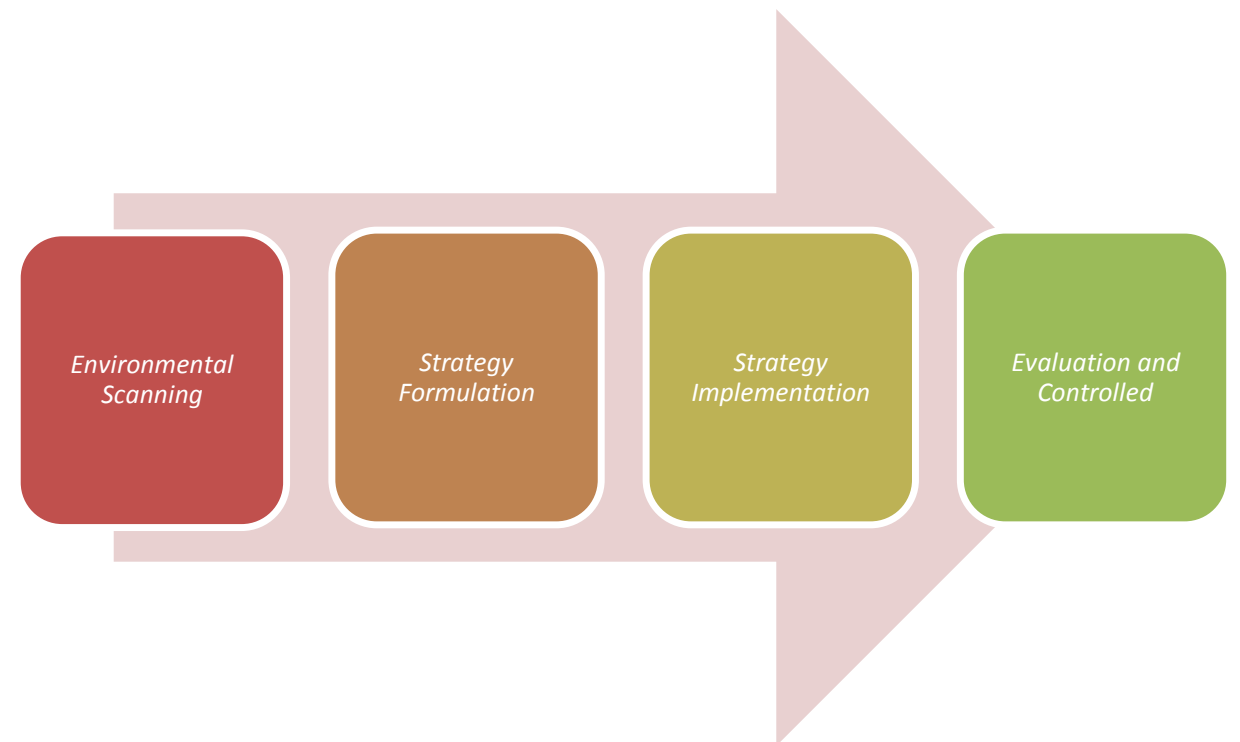

Figure 1. Basic Elements of Strategic Management Process

Source: Wheelen \& Hunger (2011)

\subsection{Implementation of Deradicalization for Terrorist Prisoners in Super Maximum Security of Correctional Institution}

Reconceptualization of prison radicalization has summarized the risks of prisoners, whether they are immediately convicted of acts relating to extremism or vandalism, whether detained or not (Clifford, 2018).

Correctional Institutions make opportunities for deradicalization increasingly difficult due to indicators in the assessment of the needs and risks to prisoners of different levels of risks. The Directorate General of Correctional Affairs provides the implementation of treatment for highrisk prisoners/terrorist prisoners following the level of needs and risk of prisoners.

The assessment of high-risk prisoners is identified based on risk assessments and assessments according to the Regulation of the Minister of Law and Human Rights of Republic of Indonesia Number 12, Year 2013, concerning Risk Assessment and Assessment of Needs for Prisoners and Correctional Clients (Haryono, 2017).

Correctional Institutions specially designed with the category of Super Maximum Security will limit the space for movement and anticipate the occurrence of security disturbances and order of terrorist prisoners as an effort to Revitalize Correctional Program regulated in the 
Regulation of the Minister of Law and Human Rights of Republic of Indonesia Number 35, Year 2018 (Kementerian Hukum dan Hak Asasi Manusia Republik Indonesia, 2018).

\section{Research Methodology}

This research used a descriptive qualitative research approach that described findings and phenomena that occurred in the field through direct observation, interviews, and research sources based on scientific studies and theoretical approaches (Tobing et al., 2016). Strategic management research in treatment for terrorist prisoners in Class 1 Correctional Institution of Batu Nusakambangan used in-depth interviews with several research sources, which consist of the Chief of Class 1 Correctional Institution of Batu Nusakambangan and terrorist prisoners to prove the truth of information by connecting theories and scientific studies (Rahmat, 2009).

The data analysis technique is the process of compiling, grouping data, and determining themes or patterns to understand the meaning. Data analysis was collected based on data found in the field, constructed into hypotheses and theories. After testing hypotheses and theories, it will be concluded by comparing the suitability of the subject's statement with the meaning contained with various research concepts (Sahid, 2011).

The informants in this study were the Chief of Class 1 Correctional Institution of Batu Nusakambangan and terrorist prisoners based on the level of radicalization, ranging from high radical levels to low radical levels. The terrorist prisoner informants consisted of Abrory, Ahmad Supriyanto, and Cecep Suherman. In addition, research informants were selected using purposive sampling techniques by determining the characteristics of research objectives to be able to answer research questions.

\section{Results and Discussion}

\subsection{Strategic Management for Terrorist Prisoners}

Based on the results of research on several components, the prison strategic management for terrorism in Class 1 Correctional Institution of Batu Nusakambangan is described through several components, which consist of Human Resources, Standard Operating Procedures, Tools and Technology, Coaching Budgets, and Coaching Materials for terrorism-specific prisoners. The component uses the Strategic Management Theory known as the S.W.O.T analysis.

The components are Strengths (S), Weaknesses $(\mathrm{W})$, Opportunities $(\mathrm{O})$, and Threats $(\mathrm{T})$, the data obtained through interviews and assessments from officers in Class 1 Correctional Institution of Batu Nusakambangan.

Table 1. The Components of Strategic Management in Class 1 Correctional Institutions of Batu Nusakambangan

\begin{tabular}{|c|c|c|}
\hline COMPONENT & INDICATOR & RESULT \\
\hline \multirow{5}{*}{ Human Resources } & Education & Good \\
\hline & Training and Skills & Good \\
\hline & Work Experience & Fair \\
\hline & Use of Firearms & Good \\
\hline & Technology Mastery & Fair \\
\hline
\end{tabular}

Copyright ( ) 2020. Owned by Author(s), published by Society. This is an open-access article under the CC-BY-NC-SA license. 
Strategic Management of Treatment for Terrorist Prisoners in Class 1 Correctional Institution of Batu Nusakambangan

\begin{tabular}{|c|c|c|}
\hline COMPONENT & INDICATOR & RESULT \\
\hline \multirow{5}{*}{$\begin{array}{c}\text { Standard Operating } \\
\text { Procedures }\end{array}$} & Security of Penitentiary Residents & Good \\
\hline & Penitentiary Residents Guard & Good \\
\hline & Penitentiary Residents Enforcement & Good \\
\hline & Penitentiary Residents Escort & Good \\
\hline & Prevention of Penitentiary Residents & Good \\
\hline COMPONENT & INDICATOR & RESULT \\
\hline \multirow{5}{*}{ The Coaching Budget } & Religious Formation & Good \\
\hline & Legal Awareness Development & Very Poor \\
\hline & Coaching Nation and State & Poor \\
\hline & Psychology Counseling & Very Poor \\
\hline & CSR & Very Poor \\
\hline COMPONENT & INDICATOR & RESULT \\
\hline \multirow{5}{*}{ Tools and Technology } & Security Tools & Good \\
\hline & Sterile and Fencing Areas & Good \\
\hline & Electricity & Good \\
\hline & Infrastructures / Rooms & Fair \\
\hline & Technology & Fair \\
\hline COMPONENT & INDICATOR & RESULT \\
\hline \multirow{5}{*}{$\begin{array}{l}\text { Coaching Materials } \\
\text { and Services }\end{array}$} & Personality Coaching Program & Very Poor \\
\hline & $\begin{array}{l}\text { Coaching and Community Research } \\
\text { Advanced Program }\end{array}$ & Good \\
\hline & Integration Program & Good \\
\hline & $\begin{array}{l}\text { Correctional Observation Team } \\
\text { Session }\end{array}$ & Good \\
\hline & Registration and Placement & Good \\
\hline
\end{tabular}

\section{Source: Primary Data (2019)}

Some components as shown in Table 1, based on the analysis of research related to strategic management in treatment terrorist prisoners as an effort to de-radicalize terrorist prisoners, it can be concluded that in the first component, Human Resources, has good assessment results, which are shown based on Education indicator to Technology Mastery indicator.

The second component, the Standard Operational Procedure, shows the results of an excellent assessment of several indicators, ranging from the Security of Penitentiary Residents indicator to the Prevention of Penitentiary Residents indicator.

The third component, the Coaching Budget, shows that the overall assessment results are very poor, only indicators of Religious Formation that show good assessment results, but from

Copyright (C) 2020. Owned by Author(s), published by Society. This is an open-access article under the CC-BY-NC-SA license. https://doi.org/10.33019/society.v8i1.171 
Legal Awareness Development indicator to Corporate Social Responsibility (CSR) the indicator shows very poor assessment results.

The fourth component, Tools and Technology, shows that the overall assessment results are good, only Infrastructures/Rooms indicator and Technology indicator that show fair assessment results.

The fifth component, Coaching Materials and Services, shows that the overall assessment results are good, only the Personality Coaching Program indicator that shows the assessment results are very poor.

In conclusion, the strategic management component in accordance with Table 1 above shows that the results achieved vary depending on several indicators, especially in the Coaching Budget and Coaching Materials and Services. There is a need to increase the Coaching Budget and treatment for terrorist prisoners and provide training and assistance for prison officials to improve law enforcement and de-radicalization efforts.

\subsection{Implementation of Deradicalization for Terrorist Prisoners in Super Maximum Security of Correctional Institution}

The aims of treatment for terrorist prisoners as an effort to deradicalize terrorism and policymaking is based on the Decree of the Director General of Correctional Affairs Number PAS-24.OT.02.02, Year 2018 concerning Technical Guidelines for Treatment Terrorism. In addition, as applied in the guidelines for treating terrorism, the Directorate General of Correctional Affairs decides several components related to the guidelines in 2017 (Firdaus, 2017). There are four components related to treatment for terrorist prisoners in Class 1 Correctional Institution of Batu Nusakambangan, as follows:
a) Religious Awareness
b) National and State Awareness
c) Legal Awareness
d) Psychology Counseling

The Regulation of the Directorate General of Correctional Affairs explained the four basic components related to terrorist prisoners, which include Treatment Religious Awareness, National and State Awareness, Legal Awareness, and Psychological Counseling. The treatment for terrorist prisoners as a deradicalization effort in Class 1 Correctional Institution of Batu Nusakambangan involves several institutions, consisting of the Special Detachment 88 AntiTerror (Densus 88), the National Counterterrorism Agency, the Ministry of Religion, and the community.

Also, Class 1 Correctional Institution of Batu Nusakambangan has cooperated with several organizations such as Non-Government Organization, which consist of Indonesian Psychology Association, Terrorism Study Institute and Central Detention Studies of Correctional for making researching about the treatment of terrorism as an effort to deradicalization in terms of planning achievement from Directorate General Of Correctional Affairs. Related to Technical Implementation, Class 1 Correctional Institution of Batu Nusakambangan has cooperated with The International Criminal Investigate Training Assistance Program (ICITAP) in terms of resource development, which consist of the Correctional Officers (COs) and Emergency Response Team (ERT) in aim for preventing disturbance of security and order in Class 1 Correctional Institution of Batu Nusakambangan.

As explained by Mr. Erwedi Supriyatno as Chief of Class 1 Correctional Institution of Batu Nusakambangan, as follows:

Copyright (C 2020. Owned by Author(s), published by Society. This is an open-access article under the CC-BY-NC-SA license. https://doi.org/10.33019/society.v8i1.171 
"Class 1 Correctional Institution of Batu Nusakambangan, related to strategic management in treatment for terrorist prisoners, has made some strategic efforts including coordinating with the Cilacap Regency Forkominda and local law enforcement agencies such as The National Counterterrorism Agency, Cilacap City Resort Police Station, and also Non-governmental organization such as Community Care Prisons and other organizations and volunteers who are willing to help in technical matters to collaborate with us", (Interview, 2019).

In treatment for terrorist prisoners, the Directorate General of Correctional Affairs cooperates with the National Counterterrorism Agency and the Ministry of Religion in terms of the efforts to deradicalize terrorist prisoners which include Treatment Religious Awareness by Islamic religious mentors, monotheism, and Islam from the Ministry of Religion, and religious lectures through audio speakers in collaboration with the Department of Religion. Also, treatment for prisoners includes personal and room cleanliness, air circulation, sports activities, and visiting services. In addition, to determine the appropriate treatment of terrorist prisoners is conducted by assessing the risks and needs by assessors from the Directorate General of Correctional Affairs and conducting community research by Probation Officers for terrorism barriers. After community assessment and research, the Correctional Assessment Team provides advice and suggestion to the team including the Probation Officers and law enforcement agencies in the best possible effort to deal with terrorist prisoners. This session was held for terrorist prisoners by involving several institutions to determine the best guidelines following the criteria, as well as the conditions of terrorist prisoners.

In addition, there is supervision and assistance by Terrorism Advocates in Class 1 Correctional Institution of Batu Nusakambangan which treatment and classifies the level of radicalization of terrorist prisoners. The assessment is based on prisoner behavior identified by the Correctional Institution through daily records obtained from CCTV. Changes in behavior are the basis of the assessment that will be a recommendation for the Probation Officer in making the best decisions for terrorist prisoners. In addition, the data will be combined with data from the National Counterterrorism Agency based on standard methods to classify the deradicalization of individual prisoners by the National Counterterrorism Agency.

The following table describes specifically the terrorist prisoners in Class 1 Correctional Institution of Batu Nusakambangan.

Table 2. Terrorist Data Based on Crime Period and Level Radicalism Category

\begin{tabular}{|c|c|c|}
\hline NO & Name & Crime Period/Level Category \\
\hline 1 & MANSYUR ALS MANCUC & $\begin{array}{c}18 \text { Years } \\
\text { High }\end{array}$ \\
\hline 2. & IWAN DARMAWAN MUTHO ALS ROIS & $\begin{array}{c}\text { Death Penalty } \\
\text { High }\end{array}$ \\
\hline 3. & ABRORY ALS AL AYUBBY & $\begin{array}{c}\text { Life Imprisonment } \\
\text { High }\end{array}$ \\
\hline 4. & SYAWALUDIN PAKPAHAN ALS ABU FADI & $\begin{array}{c}19 \text { Years } \\
\text { High }\end{array}$ \\
\hline 5. & ABDULLAH UMMITY ALS DULLAH & $\begin{array}{c}\text { Life Imprisonment } \\
\text { High }\end{array}$ \\
\hline
\end{tabular}

Copyright (C 2020. Owned by Author(s), published by Society. This is an open-access article under the CC-BY-NC-SA license. https://doi.org/10.33019/society.v8i1.171

211 
Strategic Management of Treatment for Terrorist Prisoners in Class 1 Correctional Institution of Batu Nusakambangan

\begin{tabular}{|c|c|c|}
\hline NO & Name & Crime Period/Level Category \\
\hline 6. & ISKANDAR ALS. ALEXANDER RUMAERY & $\begin{array}{l}6 \text { Years } \\
\text { Medium }\end{array}$ \\
\hline 7. & ACHMAD SUPRIYANTO ALS UMAR & $\begin{array}{l}6 \text { Years, Fined IDR } 50 \text { Million } \\
\text { Medium }\end{array}$ \\
\hline 8. & SUYANTO ALS ABU IZZA & $\begin{array}{c}9 \text { Years } \\
\text { Medium } \\
\end{array}$ \\
\hline 9 & BAHRUDDIN AHMAD ALS ABU UMAR & $\begin{array}{l}10 \text { Years } \\
\text { Medium }\end{array}$ \\
\hline 10 & ZAINAL ANSORI BIN MOHAMMAD ALI & $\begin{array}{l}7 \text { Years } \\
\text { Low }\end{array}$ \\
\hline 11 & PRIYO HADI PURNOMO ALS AZ ZUFAR & $\begin{array}{l}5 \text { Years } \\
\text { Low }\end{array}$ \\
\hline 12 & SUPARMAN ALS MAHER & $\begin{array}{c}5 \text { Years } \\
\text { Low } \\
\end{array}$ \\
\hline 13. & ZULKARNAEN ALS ZUL & $\begin{array}{l}4 \text { Years } 5 \text { Month } \\
\text { Low }\end{array}$ \\
\hline 13. & ABDUL KHODIR ALS YAZID & $\begin{array}{c}3 \text { Years } 6 \text { Month } \\
\text { Low }\end{array}$ \\
\hline 15. & CECEP SUPARMAN & $\begin{array}{l}4 \text { Years } \\
\text { Low }\end{array}$ \\
\hline 16 & $\begin{array}{l}\text { HERI SURANTO ALS ABU NAILA BIN } \\
\text { PADMO SUWITO }\end{array}$ & $\begin{array}{c}5 \text { Years } \\
\text { Low }\end{array}$ \\
\hline 17. & DORI GUSVENDI BIN ABU SAHADA & $\begin{array}{c}5 \text { Years, Fined IDR } 50 \text { Million } \\
\text { Low }\end{array}$ \\
\hline 18. & SUNANTO ALS ABU ARSAL & $\begin{array}{c}3 \text { Years } 6 \text { Month } \\
\text { Low }\end{array}$ \\
\hline
\end{tabular}

Source: Primary Data (2019)

Based on the results of interviews with several terrorist prisoners, which consist of Abrory (High Level), Achmad Supriyanto (Medium Level), and Cecep Suparman (Low Level) related to the benefits of treatment for terrorist prisoners as an effort to deradicalize the treatment of terrorist prisoners, as follows:

1) Abrory (High Level)

"During my time in Class 1 Correctional Institution of Batu Nusakambangan, I was treated differently, and I also placed in a special cell/block. I was involved in several treatments but less when compared to other terrorists who have different levels from me. Besides, I was involved in some treatment including religious treatment such as learning activities, religious lectures, and religious counseling accompanied by mentors. However, my rights are given less than others, I spend all day in my cell", (Interview, 2019).

Based on the literature review above, it is said that strategic management in the treatment for terrorist prisoners can be provided by the method of separating terrorist prisoners according

Copyright (C) 2020. Owned by Author(s), published by Society. This is an open-access article under the CC-BY-NC-SA license. https://doi.org/10.33019/society.v8i1.171 
to the level of radicalization, starting from the highest level of radicalization to the lowest level of radicalization. This is related to Abrory's statement, which stated that Abrory was placed in a different cell/block and spends all day in the cell due to significant differences in treatment and safety. Also, for high levels of radicalization, it can be seen by using environmental scanning using the S.W.O.T. system. It aims to anticipate risks and control treatment for terrorist prisoners of high-level radicalization.

\section{2) Achmad Supriyanto (Medium Level)}

"During my time in Class 1 Correctional of Batu Nusakambangan Institution, I was involved in intensive treatment including religious treatment such as learning activities, religious lectures, and religious counseling accompanied by mentors and also national and state awareness. In addition, mentors taught me about self-potential development as supplementary material", (Interview, 2019).

In addition to strategic management in the placement of prisoners, the implementation of strategy formulation, and strategy implementation, as stated in Wheelen's and Hunger's theory, intensive treatment for strategy formulation can reduce the risk of radicalization of terrorist prisoners. Achmad Supriyanto said that he involved in intensive treatment and self-potential development. This can minimize the risk of radicalization and reduce the level of radicalization.

\section{3) Cecep Suparman (Low Level)}

"During my time in Class 1 Correctional of Batu Nusakambangan Institution, I was involved in intensive treatment including religious treatment such as learning activities, religious lectures, and religious counseling accompanied by mentors, selfpotential development, and also national and state awareness. I also accept Indonesia as my nationality. Most important that I got intensive treatment for life skills such as farming skills and other skills depending on the skill of each other", (Interview, 2019).

At the minimum level of radicalization, based on the theory of strategic management by Wheelen and Hunger, evaluations and controls are conducted in preparation for terrorist prisoners when they are released from Super Maximum/High-Risk Prisons to Low-Security Prisons. At this level, terrorist prisoners got an evaluation from a mentor through treatment awareness including a statement of nationality. According to Cecep Suherman, he was involved in intensive and special treatment such as farming skills in preparation when he released from Maximum Security Prison/High-Risk Prison. In addition, supervision from mentors at this level is very intensive to maximize the strategic management function.

\section{Conclusion}

In the strategic management research of treatment for terrorist prisoners as an effort to deradicalization in Class 1 Correctional Institution of Batu Nusakambangan, can be concluded that: 1) the implementation of strategic management in treatment for terrorist prisoners in Class 1 Correctional Institution of Batu Nusakambangan as a deradicalization effort, in this case, used a pattern of strategic management that is implemented through S.W.O.T. analysis. 2) The implementation of treatment for terrorist prisoners in Class 1 Correctional Institution of Batu Nusakambangan is still very limited, which consists of religious awareness treatment and 
national and state awareness treatment. There is no good cooperation between law enforcement institutions and government institutions related to treatment for terrorist prisoners including the Ministry of Religion, Legal Aid Institute, and Psychology Team to conduct psychological counseling.

\section{Acknowledgment}

The authors would like to thank all the informants who provided assistance and information during the research conducted.

\section{Declaration of Conflicting Interests}

The authors declared no potential conflicts of interest concerning the research, authorship, and/or publication of this article.

\section{References}

Berty, T. T. S. (2018, September 10). 10 Fakta di Balik Tragedi 9/11 yang Terjadi 17 tahun Silam. Retrieved from https://www.liputan6.com/global/read/3640694/10-fakta-di-baliktragedi-911-yang-terjadi-17-tahun-silam

Borum, R. (2004). Psychology of terrorism. Tampa: University of South Florida.

Clifford, B. (2018). Radicalization in Custody: Towards Data-Driven Terrorism Prevention in the United States Federal Correctional System. Policy Paper. Program on Extremism. https://extremism.gwu.edu/sites/g/files/zaxdzs2191/f/Prisons\%20Policy\%20Paper.pdf

CNN Indonesia (2019, June 04). Rentetan Bom dan Aksi Terorisme Selama Ramadan di Indonesia. Retrieved from https://www.cnnindonesia.com/nasional/20190604110800-20400871/rentetan-bom-dan-aksi-terorisme-selama-ramadan-di-indonesia?

Deflem, M. (2004). Towards A Criminological Sociology of Terrorism and Counter-Terrorism. In Sociology of Crime, Law and Deviance (Terrorism and Counter-Terrorism ed., Vol. 5, pp. 16). Bingley, United Kingdom: Emerald Group Publishing Limited. https:/ / doi.org/10.1108/S1521-6136(2004)0000005002

Firdaus, I. (2017). Penempatan Narapidana Teroris di Lembaga Pemasyarakatan. Jurnal Penelitian Hukum De Jure, 17(4), 429-443. http:/ / dx.doi.org/10.30641/dejure.2017.V17.429443

Haryono, H. (2017). Kebijakan Perlakuan Khusus terhadap Narapidana Risiko Tinggi di Lembaga Pemasyarakatan (Studi Kasus di Lembaga Pemasyarakatan Kls III Gn. Sindur). Jurnal Ilmiah Kebijakan Hukum, 231-247. https:/ / ejournal.balitbangham.go.id/index.php/kebijakan/article/view/311

Kementerian Hukum dan Hak Asasi Manusia Republik Indonesia. (2017). Naskah Akademik Rancangan Undang-Undang Tentang Pemasyarakatan. Retrieved from https://www.bphn.go.id/data/documents/na_ruu_pemasyarakatan.pdf

Kementerian Hukum dan Hak Asasi Manusia Republik Indonesia. (2018, December 20). Peraturan Menteri Hukum dan Hak Asasi Manusia Republik Indonesia Nomor 35 Tahun 2018 Tentang Revitalisasi Penyelenggaraan Masyarakat. Retrieved from http:/ / ditjenpp.kemenkumham.go.id/arsip/bn/2018/bn1685-2018.pdf

Mappasiara, M. (2018). Manajemen Strategik Dan Manajemen Operasional Serta Implementasinya Pada Lembaga Pendidikan. Idaarah: Jurnal Manajemen Pendidikan, 2(1), 74-85. https://doi.org/10.24252/idaarah.v2i1.5116 
Prahassacitta, V. (2016). The Concept of Extraordinary Crime in Indonesia Legal System: is The Concept An Effective Criminal Policy?. Humaniora, 7(4), 513-521. https://doi.org/10.21512/humaniora.v7i4.3604

Putri, T. H. (2018, May 26). Awal Mula Gerakan Terorisme Indonesia hingga Rentetan Bom Mei 2018. Retrieved from https://www.idntimes.com/news/indonesia/teatrika/awal-mulagerakan-terorisme-indonesia-hingga-rentetan-bom-mei

Rahmat, P. S. (2009). Penelitian Kualitatif. EQUILIBRIUM, 5(9), 1-8. http:/ / yusuf.staff.ub.ac.id/files/2012/11/Jurnal-Penelitian-Kualitatif.pdf

Republik Indonesia. (2013, March 13). Undang-Undang Republik Indonesia Nomor 9 Tahun 2013 Tentang Pencegahan dan Pemberantasan Tindak Pidana Pendanaan Terorisme. Retrieved from https:/ / peraturan.go.id/common/dokumen/ln/2013/uu9-2013bt.pdf Royal Canadian Mounted Police. (2010). Departmental Performance Report 2009-2010. Ottawa, Canada: Author. https:/ / www.tbs-sct.gc.ca/dpr-rmr/2009-2010/inst/rcm/rcm-eng.pdf Sahid, R. (2011). Analisis Data Penelitian Kualitatif. Depok: Raja Grafindo Persada.

Sumpter, C., Wardhani, Y. K., \& Priyanto, S. (2019). Testing Transitions: Extremist Prisoners ReEntering Indonesian Society. Studies in Conflict $\mathcal{E}$ Terrorism, 1-22. https://doi.org/10.1080/1057610x.2018.1560666

Tapera, J. (2014). The Importance of Strategic Management to Business Organizations. Research Journal of Social Science \& Management, 3(11), 122-131. https://www.theinternationaljournal.org/ojs/index.php?journal=tij\&page=article\&op=vi ew\&path $\% 5 \mathrm{~B} \% 5 \mathrm{D}=2700 \&$ path $\% 5 \mathrm{~B} \% 5 \mathrm{D}=\mathrm{pdf}$

Tobing, D. H., Herdiyanto, Y. K., Astiti, D. P., Rustika, I. M., Indrawati, K. R., Susilawati, L. K. P. A., \& All, E. (2016). Bahan Ajar Metode Penelitian Kualitatif. Program Studi Psikologi Fakultas Kedokteran Universitas Udaya.

Wheelen, T. L., \& Hunger, J. D. (2011). Strategic Management and Business Policy: Toward Global Sustainability (Thirteenth ed.). Upper Saddle River, NJ, United States: Prentice Hall.

\section{About the Authors}

1. Rachmayanthy, obtained her Doctoral degree from Universitas Negeri Jakarta, Indonesia, in 2011. The author is Director Polytechic of Correctional Science and Assistant Professor at Department of Correctional Engineering, Polytechnic of Correctional Science, Depok, Indonesia.

E-Mail: yanthyrachma@yahoo.co.id

2. Okki Oktaviandi, the alumni of Department of Correctional Management, Polytechnic of Correctional Science, Depok, Indonesia.

E-Mail: okkioktaviandi49@gmail.com

3. Padmono Wibowo, obtained his Doctoral degree from Universitas Negeri Jakarta, Indonesia, in 2012. The author is an Assistant Professor at Department of Correctional Management, Polytechnic of Correctional Science, Depok, Indonesia.

E-Mail: padmonowibowo@yahoo.co.id 
4. Syahrial Yuska, obtained his Doctoral degree from Airlangga University, Indonesia, in 2012. The author is an Assistant Professor and Head of Department of Correctional Management, Polytechnic of Correctional Science, Depok, Indonesia.

E-Mail: syahyuska@gmail.com 